\title{
Article
}

\section{Migrants, Family and the State: Be/coming Taiwanese in a Transnational World}

Momesso, Lara and Cheng, Isabelle Available at http://clok.uclan.ac.uk/21076/

Momesso, Lara ORCID: 0000-0002-4042-9384 and Cheng, Isabelle (2017) Migrants, Family and the State: Be/coming Taiwanese in a Transnational World. Asian and Pacific Migration Journal, 26 (4). pp. 405-412. ISSN $0117-$ 1968

It is advisable to refer to the publisher's version if you intend to cite from the work. http://dx.doi.org/10.1177/0117196817747059

For more information about UCLan's research in this area go to http://www.uclan.ac.uk/researchgroups/ and search for <name of research Group>.

For information about Research generally at UCLan please go to http://www.uclan.ac.uk/research/

All outputs in CLoK are protected by Intellectual Property Rights law, including Copyright law. Copyright, IPR and Moral Rights for the works on this site are retained by the individual authors and/or other copyright owners. Terms and conditions for use of this material are defined in the policies page.

\section{CLoK}

Central Lancashire online Knowledge www.clok.uclan.ac.uk

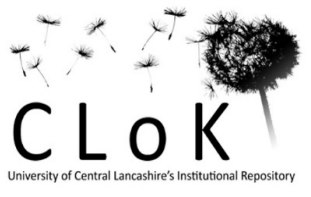




\title{
Migrants, Family and the State: Be/coming Taiwanese in a Transnational World
}

\author{
Guest Editors: \\ Lara Momesso, University of Central Lancashire \\ Isabelle Cheng, University of Portsmouth
}

\section{Introduction: Taiwan in a transnational world}

In the past three decades, significant turns in migration studies saw the emergence of transnationalism as an analytical framework with which to understand contemporary cross-border movements enabled by globalization and advances in the means of communication and transportation. With the aim of going beyond the understanding of the lives of migrants as conditioned by the institutions of nationstates, and also to shed light on the changing conditions of global capitalism, scholarship on transnational migration argues that social inquiry should approach migration phenomena from the perspective of migrants' lives and focus on the social spheres emerging from their engagement with the global world (Glick-Schiller et al., 1992; Glick-Schiller et al., 1995; Guarnizo and Smith, 2008; Portes et al., 1999; Vertovec, 2009). In the words of Amelina and Faist (2012: 1708), transnational migration studies 'de-naturalized' categories such as nation and space and opened new possibilities to understand multiplicity, multi-locality, hybridity, and diversity in migrants' lives, identities and practices. Among others, transnational migration scholarship not only challenges the dichotomy between the local and global, but also establishes a conceptual link between different localities and social fields in migrants' lives and practices.

Since it surfaced in the field of migration studies, transnationalism has evolved in different directions. Focusing on the individual at the micro level, earlier literature on transnational migration studies often celebrated the agency of migrant actors in shaping their social universes. In contrast, recent debates have offered more problematized accounts which reconsidered the lingering significance of structural forces and the ways in which the emerging and changing structures of opportunities and constraints in the world system 'foster, shape, [and] disable local agency' (Lazar, 2011: 76). Most of these later accounts illuminated the experiences of contemporary migrants that are framed by the hierarchy of the global capitalist economy. As a result, dynamism arose from the interactions between the individual and the structural forces at the global and national levels. Yet, this emphasis on the uneven distribution of power and wealth in the core, semi-periphery and periphery zones runs the risk of dichotomizing the experiences of transnational actors. As a result, the world appears polarized between a well-off population, who enjoy the benefits of new patterns of 'flexible accumulation,' and a 'super-exploited' 
population, who are unable to control their own destiny (Robinson, 1998: 578). This dichotomous view also characterizes the scholarship on East Asian migrations, divided between celebratory accounts of new opportunities offered to transnational Asian elites, especially those from richer societies in the region such as Singapore, Taiwan and Hong Kong (Ong, 1999; Pe-Pua et al., 1996; Yeoh et al., 2005), and the constraints and problems faced by transnational workers and marriage migrants from poorer countries such as China, Vietnam, Indonesia, and the Philippines (Cheng, 2013; Davin, 2007; Sandel, 2015; So, 2003; Suzuki, 2003; Tsai, 2011; Wang and Chang, 2002).

Using the case of Taiwan as an example, the articles in this special section build on the idea that the role of the nation-state in transnational migrations should be revisited to robustly assess how migrants' experiences are shaped not only by their country of origin but also by other factors, including social, ethnic, economic, and political background. To do so, this thematic section employs the concept of intersectionality, an approach extensively used by transnational feminists (Al-Ali and Pratt, 2009; Higginbotham, 1992; King, 1988; Mohanty, 2003), that brings together different levels of analysis so as to grasp the dynamism and contradictions of transnational experiences. These different dimensions include national specificity, local and regional dynamics, and the positioning of individuals in the social hierarchies constituted by gender, class and ethnicity. Adopting intersectionality for analyzing transnational migration phenomena not only offers a triangulated view of individual migrants' experiences as conditioned by the uneven distribution of power and wealth among nation-states, but also elucidates how the nation-state reinvigorates itself by utilizing regional resources and transnational actors to maintain control of its borders and the boundaries of national community.

The commonality and uniqueness of migration to and from Taiwan lend itself to intersectional analysis. With its growing significance as an origin, transit and destination country of transnational movements, Taiwan is an illustrative case whereby critical questions of integration, exclusion, belonging, and the resistance of migrants can be examined through transnationalism as an analytical framework. Since democratization and economic liberalization were set in motion three decades ago, Taiwan has become a prominent site for international migration. In the past three decades, the state of Taiwan has endeavored to control its borders, maintain the emotive bond with its citizens abroad, navigate the geographical and sectoral distribution of overseas investment, integrate migrants for national cohesion and social stability, rein in the expansion and intensification of socio-economic contacts with China, and manage the tensions in its relationship withChina. These efforts are underlined by its intention to benefit from the global division of labor and regional interdependence. At the same time, it also strives 
to reduce the costs and challenges of accommodating foreign-born residents and citizens whose desirability is measured by their contributions to production and reproduction.

In its transformation as a destination country, Taiwan seeks to lure foreign talents and skills with permanent residency, regulate the recruitment and temporary stay of less skilled foreign workers, and incorporate marriage migrants, a highly feminized migration. Unlike other international migrants, foreign wives from China and Southeast Asia become, or are expected to be, constituent members of the national community because of their marriage to Taiwanese nationals and as mothers of future Taiwanese citizens. Their integration is hindered by a reluctant state deriving from gender, nationality, ethnicity and class biases. Caught between realizing normative values of multiculturalism and protecting the interests of patriarchy and nationalism, Taiwan's policies toward marriage migrants simultaneously aims to assimilate and discipline foreign women to be chaste wives and capable mothers (Cheng, 2013; Cheng and Fell, 2014; Momesso, 2016; Sandel and Liang, 2010).

Within the context of the global division of labor and framed by nationalist projects of migrants' natal states and Taiwan, individual migrants - whether in their private homes, in their workplaces, or in the streets - also exercise their agency to improve their lives. In addition, migrants strive to maintain their ties with their families in the home countries and create links between their natal states and Taiwan. In these institutional or informal acts, global forces, regional dynamics, national interests and personal autonomy intersect. In this regard, Taiwan's experience in international migration and its ramifications is not unique.

Although Taiwan's migration experience shares some commonalities with other states, not being universally recognized as a sovereign state makes Taiwan a special case. The lack of wide international recognition renders exceptional difficulties not only for the state of Taiwan to exert its sovereignty over foreign nationals in its territory but also affects the status of its nationals abroad. Problems caused by the lack of recognition are rooted in China's refusal to recognize Taiwan's jurisdiction over the island's territory. This refusal, nonetheless, did not impede the flow of Taiwanese investments into China and benefit from China's greater production capacity and expanding market. As a global magnet for jobs, opportunities, and orientalist curiosities and exoticness, China, particularly its cosmopolitan cities on the coast, also became a significant base for meeting the desires and adventures of the Taiwanese expatriate community (Shih 1998). In the context of mutual antagonism between Taiwan and China and the persistent threat of invasion by Chinese military forces, the state of Taiwan does not 
enjoy much leverage in reducing further economic dependence on China's production capacity and consumption power. Nor is the Taiwanese state able to prevent Taiwanese businesspeople from receiving the enticing privileges offered by China. What the state of Taiwan seems to achieve, however, is to regulate the admission of Chinese migrants to the island's citizenry in the interest of national security and nation-building.

Informed by intersectionality, the exceptional case of Taiwan brings to the fore its complexity as an origin and destination of migrants that is otherwise often limited by its national context. This junction, between commonality and exceptionality, provides the point of departure for this thematic section in which we assess whether and how the nation-state, in its material and ideological manifestations respond to the forces of globalization and the transnational movements of people, capital, ideas and commodities.

The set of papers included in this section deal with different empirical cases to discuss the impact of Taiwan's status on the everyday lives of migrants. Yu-chin Tseng's paper "Rapprochement at the third place: Chinese-Taiwanese couples in the UK" interrogates the unexplored case of cross-Strait couples in third countries. It looks into the couples' decision-making processes related to marriage, marriage life, and migration against structural conditions embodied by migration and marriage policies of the three states (Taiwan, China and a third country) that the couples have to navigate, as well as the political tensions produced by cross-Strait relations. The existing literature has documented and analyzed the problems faced by cross-Strait families in Taiwan due to political tensions between China and Taiwan (Friedman, 2010; Momesso, 2017; Momesso and Cheng 2017; Yang and Lee, 2009). Tseng's research pushes this debate further by discussing how cross-Strait relations transcends their borders and affects these families' experiences in third countries.

Taking a different angle, Isabelle Cheng's article_- “ Reality or Pretense? Renouncing Nationality and Organized Hypocrisy of the Sovereignty of Taiwan --focuses on marriage migrants' naturalization and household registration processes in the context of Taiwan's contested sovereignty. By juxtaposing the different requirements for naturalization applied to foreign spouses and mainland Chinese spouses, the paper makes the case for the hypocrisy of the sovereignty of the Taiwanese state. As Cheng argues, the hypocrisy of Taiwan's sovereignty shows in its legislation of demanding that migrant spouses renounce their native nationality or cancel their household registration in China, a demand that may result in the failure of the origin state to assume the moral responsibility of preventing statelessness but also invites 
the origin state to recognize or deny Taiwan's sovereignty.

Finally, the paper_-“Transnational mobility, strong states, and contested sovereignty: Learning from the China-Taiwan context"-by Lara Momesso and Chun-yi Lee examines two forms of complementary yet distinct cross-Strait movements, namely, Taiwanese investors living in China and Chinese marriage migrants living in Taiwan. Their research focuses on how these two groups responded to Chinese authorities' policies at different stages of cross-Strait relations since the resumption of exchanges across the Strait in 1987. Their paper suggests that cross-Strait migratory movements did not weaken China's authority and power, but . instead became a new channel to promote and support its nationalistic goal of a reunified China under the rule of the Communist Party..

With these central themes and drawing from the peculiarity of the case of Taiwan, this collection aims to contribute to the scholarship on transnational movements by presenting original empirical data and employing innovative conceptual and theoretical approaches. The analyses suggest that contemporary migrants, while disengaging from the authority and control of the state as a consequence of their transnational movements and practices, may also end up being maneuvered and governed by state actors, and, eventually, supporting the nationalist ideologies of the state. One assumption shared by the papers here is that under conditions of globalization and high levels of transnational mobility, the authority of the nation-state over migrant communities is challenged by its negotiation with a multiplicity of actors at various levels-- international, regional and local - and is engagement with migrant communities.

A further insight emerging from the papers is the impact of Taiwan's status in the international community on the legal status and rights of migrants, depending on migrants' geographical, social, and political positionalities. Tseng (this volume) argues that in response to structural constraints generated by cross-Strait politics, restrictive immigration rules, and favorable social welfare, cross-Strait couples in third countries may decide to marry for convenience. In Taiwan, marriage migrants from Vietnam and mainland China, trapped between the political issues of Taiwan's unrecognized sovereignty and the need to make practical decisions on whether to acquire Taiwanese nationality/household registration, may end up persuading themselves of the truthfulness of Taiwan's nationality precisely because of the choice they made. Across the Taiwan Strait, marriage migrants from mainland China and businessmen from Taiwan may decide to take advantage of the honors and benefits offered to them by Beijing, even though this meant, for Taiwanese businessmen, silencing themselves with regard to their political 
identities, and for Chinese spouses, patiently waiting for Beijing to appreciate their potential contributions.

Thus, as the papers in this special section suggest, the nation-state remains a critical category in the study of cross-border phenomena-migration itself becomes the field where statehood is strengthened and/or weakened. Yet, as the papers here indicate, the role of the nation-state in its material and ideological forms may be changed by transnational migration, but it continues to be a powerful variable in shaping the experiences and practices of transnational migrants.

\section{Acknowledgments}

These papers were first presented as part of a panel under the title of Be/coming Taiwanese in a Transnational World at the North American Taiwan Studies Association conference at the University of Toronto on 10-11 June 2016. We would like to extend our sincere thanks to the discussants and the peer reviewers, whose contributions informed all the papers presented. Any shortcomings remain our own.

\section{Declaration of conflicting interests}

The authors declared no potential conflicts of interest with respect to the research, authorship, and/or publication of this paper.

\section{Funding}

This research received no specific grant from any funding agency in the public, commercial, or not-forprofit sectors.

\section{References}

Al-Ali N and Pratt N (2009) Introduction. Women and war in the Middle East: Transnational perspectives. In: Al-Ali N and Pratt N (eds) Women and War in the Middle East: Transnational Perspectives. New York: Zed Books, pp. 1-31.

Amelina A and Faist T (2012) De-naturalising the national in research methodologies: Key concepts of transnational studies in migration. Ethnic and Racial Studies 35 (10): 1707-1724.

Cheng I (2013) Making foreign women the mother of our nation: The exclusion and assimilation of immigrant women in Taiwan. Asian Ethnicity 14(2): 157-179.

Davin D (2007) Marriage migration in China and East Asia. Journal of Contemporary China 16(50): 
83-95.

Cheng I and Fell D (2014) The change of ruling parties and Taiwan's claim to multiculturalism before and after 2008. Journal of Current Chinese Affairs, 43(3), 71-103.

Friedman S (2010) Marital immigration and graduated citizenship: Post-naturalization restrictions on Mainland Chinese spouses in Taiwan. Pacific Affairs 83(1): 73-93.

Glick-Schiller N, Basch L and Blanc-Szanton C (1992) Transnationalism: A new analytic framework for understanding migration. In: Glick-Schiller N, Basch L and Blanc-Szanton C (eds) Towards a Transnational Perspective on Migration: Race, Class, Ethnicity, and Nationalism Reconsidered. New York: The New York Academy of Science, pp. 1-24.

Glick-Schiller N, Basch L and Blanc-Szanton C (1995) From immigrant to transmigrant: Theorizing transnational migration. Anthropological Quarterly 68 (1): 48-63.

Guarnizo LE and Smith MP (2008) The location of transnationalism. In: Smith MP and Guarnizo LE (eds) Transnationalism from Below: Comparative Urban and Community Research. London: Transaction Publishers, pp. 3-34.

Higginbotham EB (1992) African-American women's history and the metalanguage of race. Signs 17(2): 251-274.

King D (1988) Multiple jeopardy, multiple consciousness: the context of black feminist ideology. Signs 14(1): 42-72.

Lazar A (2011) Transnational migration studies: Reframing sociological imagination and research. Journal of Comparative Research in Anthropology and Sociology 2(2): 69-83.

Mohanty C P (2003) 'Under Western Eyes' revisited: Feminist solidarity through anticapitalist struggles. Signs 28(2): 499-535.

Momesso L (2016) From someone, to no-one, to a new-one: A subjective view of Taiwan's immigration policies in the context of multiculturalism. In: Jens D and Cheng I (eds.) Berliner China-Hefte - Chinese History and Society. Special Issue, Taiwan: Self Versus Other, 48, 2016. Pp. 24-36.

Momesso L (2017) Marriage, migration and state interests: Reflections from the experiences of marriage migrants from the People's Republic of China in Taiwan. Asiatische Studien 70(3): 903-920. 
Momesso L and Cheng I (2017) A team player pursuing its own dreams: Rights-claim campaign of Chinese migrant spouses in the migrant movement before and after 2008. In: Dafydd F (ed) Taiwan's Social Movements under Ma Ying-jeou: From the Wild Strawberries to the Sunflowers. London: Routledge, pp. 219-235.

Ong A (1999) Flexible Citizenship: The Cultural Logic of Transnationality. London: Duke University Press.

Pe-Pua R, Mitchell C, Iredale R and Castles S (1996) Astronaut Families and Parachute Children: The Cycle of Migration between Hong Kong and Australia. Canberra: AGPS.

Portes A, Guarnizo LE and Landolt P (1999) The study of transnationalism: Pitfalls and promise of an emergent research field. Ethnic and Racial Studies 22(2): 218-237.

Robinson WI (1998) Beyond nation-state paradigms: Globalization sociology and the challenge of transnational studies. Sociological Forum 13(4): 561-594.

Sandel TL (2015) Brides on Sale: Taiwanese Cross Border Marriages in a Globalizing Asia. New York: Peter Lang.

Sandel TL and Liang CH (2010) Taiwan's fifth ethnic group: A study of the acculturation and cultural fusion of women who have married into families in Taiwan, Journal of International and Intercultural Communication, 3(3) 249-275.

Shih SM (1998) Gender and a new geopolitics of desire: The seduction of mainland women in Taiwan and Hong Kong media. Signs, 23(2): 287-319.

So AY (2003) Cross-border families in Hong Kong: the role of social class and politics. Critical Asian Studies 35(4): 515-534.

Suzuki N (2003) Transgressing 'victims.' Reading narratives of 'Filipina brides' in Japan. Critical Asian Studies 35(3): 399-420.

Tsai M-C (2011) 'Foreign brides' meet ethnic politics in Taiwan. International Migration Review 45(3): 243-268.

Vertovec S (2009) Transnationalism. London: Routledge.

Wang H-Z and Chang S-M (2002) The commodification of international marriages: Cross-border marriage business in Taiwan and Vietnam. International Migration 40(6): 93-116.

Yang W-Y and Lee P-L (2009) The citizenship dilemma of mainlander spouses in Taiwan: The 
conspiracy of nationalism and patriarchy [大陸配偶的公民權困境一國族與父權的共謀]. Taiwan Democracy Quarterly [臺灣民主季刊] 6(3): 47-86 (In Chinese).

Yeoh BSA, Huang S and Lam T (2005) Transnationalizing the 'Asian' family: Imaginaries, intimacies and strategic intents. Global Networks 5(4): 307-315. 